\title{
Prowadzenie postępowania dowodowego na rozprawie w trybie art. $378 a$ Zagadnienia wybrane
}

\begin{abstract}
This article concerns the possibility of conducting proceedings in the absence of the accused or his or her defence counsel even though they have duly justified their absence. The study discusses grounds for applying Article 378a of the Polish Code of Criminal Procedure, alongside some issues connected with submission of a motion for the supplementary taking of evidence. The paper assesses the ratio legis of Article 378a of the Polish Code of Criminal Procedure in the context of the principle of a fair criminal trial, the right to court and the right to defence. The author analyses this legal norm de lege lata and formulates de lege ferenda postulates.
\end{abstract}

Keywords: right to defense, right to court, participation of the accused in a criminal trial

\section{Uwagi wstępne}

Ustawa z dnia 19 lipca 2019 r. o zmianie ustawy - Kodeks postępowania karnego oraz niektórych innych ustaw ${ }^{1}$ wprowadziła do polskiego procesu karnego możliwość prowadzenia postępowania dowodowego na rozprawie pod nieobecność oskarżonego lub obrońcy, prawidłowo zawiadomionego o jej terminie, który należycie usprawiedliwił swoje niestawiennictwo. Przepis art. 378a k.p.k. już na etapie legislacyjnym budził liczne kontrowersje. Uwagi krytyczne do tego przepisu zgłaszali między in-

${ }^{1}$ Ustawa z dnia 19 lipca 2019 r. o zmianie ustawy - Kodeks postępowania karnego oraz niektórych innych ustaw, Dz.U. 2019, poz. 1694. 
nymi: Rzecznik Praw Obywatelskich ${ }^{2}$, Naczelna Rada wokacka ${ }^{3}$, Krajowa Izba Radców Prawnych ${ }^{4}$, podkreślając oczywiste kolizje art. 378a z zasadą prawa do sądu oraz prawa do obrony.

Sprawiedliwe postępowanie sądowe powinno zapewniać stronom uprawnienia adekwatne do jego przedmiotu. W orzecznictwie TK podkreśla się, że ocena konkretnych rozwiązań ustawowych pod kątem zgodności z zasadą sprawiedliwości proceduralnej powinna uwzględniać charakter i specyfikę danego postępowania. Nie jest więc możliwe stworzenie uniwersalnego modelu dla procesu karnego, cywilnego czy też sądowo-administracyjnego ${ }^{5}$. Postępowanie karne ma szczególnie represyjny charakter, co oznacza, że głęboko ingeruje w sferę uniwersalnych wartości relewantnych z punktu widzenia demokratycznego państwa prawa.

Przedmiotowe opracowanie zawiera uwagi de lege lata pod kątem obecnie istniejącej regulacji oraz postulaty de lege ferenda kierowane pod adresem ustawodawcy.

\section{Przesłanki stosowania instytucji}

Prowadzenie postępowania dowodowego w trybie art. 378a k.p.k. jest możliwe pod warunkiem koniunktywnego spełnienia następujących przesłanek:

- brak stawiennictwa oskarżonego lub jego obrońcy na rozprawie;

- prawidłowe zawiadomienie oskarżonego oraz jego obrońcy o terminie rozprawy;

- należyte usprawiedliwienie niestawiennictwa oskarżonego lub jego obrońcy;

2 Opinia Rzecznika Praw Obywatelskich z dnia 20 grudnia 2018 r. do projektu ustawy o zmianie ustawy - Kodeks postępowania karnego oraz niektórych innych ustaw. Źródło: https://www.rpo.gov.pl/sites/default/files/Wyst\%C4\%85pienie\%20do\%20Ministra\%20 Sprawiedliwo\%C5\%9Bci\%20w\%20sprawie\%20projektu\%20noweli\%20Kodeksu\%20 post\%C4\%99powania\%20karnego.pdf [dostęp: 15.03.2020].

${ }_{3}$ Opinia Komisji Legislacyjnej przy Naczelnej Radzie Adwokackiej do projektu ustawy o zmianie ustawy - Kodeks postępowania karnego oraz niektórych innych ustaw (Druk UD 465). Źródło: https://legislacja.rcl.gov.pl/docs//2/12318806/12554727/12554730/dokument377906.pdf [dostęp: 15.03.2020].

${ }^{4}$ Opinia Ośrodka Badań, Studiów i Legislacji Krajowej Rady Radców Prawnych do projektu ustawy o zmianie ustawy - Kodeks postępowania karnego oraz niektórych innych ustawa z dnia 17 grudnia 2018 r. Źródło: http://obsil.pl/wp-content/uploads/2018/12/ Opinia-OBSiL-z-17.12.2018-r.-projekt-zmian-KPK.pdf [dostęp: 15.03.2020].

${ }^{5}$ Wyr. TK z dnia 6 grudnia 2004 r., SK 29/04. LEX nr 140349. 
- zaistnienie szczególnie uzasadnionych wypadków przemawiających za przeprowadzeniem postępowania dowodowego per absentia, nawet jeżeli oskarżony nie złożył jeszcze wyjaśnień.

Warunkiem sine qua non skorzystania $\mathrm{z}$ art. 378a k.pk. jest prawidłowe zawiadomienie oskarżonego oraz jego obrońcy o terminie rozprawy. Brak notyfikacji albo nienależyte poinformowanie strony pasywnej uniemożliwia uruchomienie instytucji. Stosownie do art. $117 \S 1$ k.p.k. uprawnionego do wzięcia udziału w czynności procesowej zawiadamia się o jej czasie i miejscu, chyba że ustawa stanowi inaczej. Obowiązek prawidłowego zawiadomienia oskarżonego o terminie rozprawy ciąży na organie procesowym. Właściwa notyfikacja stanowi warunek sine qua non przeprowadzenia rozprawy $\mathrm{w}$ procesie karnym ${ }^{6}$. W orzecznictwie podkreśla się zasadnie, że oskarżony (ani inny uczestnik postępowania) nie może ponosić negatywnych konsekwencji niewłaściwej organizacji aparatu wewnątrzsądowego ${ }^{7}$.

Po drugie nieobecność oskarżonego lub jego obrońcy musi być usprawiedliwiona. W świetle art. $117 \S 2$ k.p.k. czynności nie przeprowadza się, jeżeli osoba uprawniona nie stawiła się, a brak dowodu, że została o niej powiadomiona, oraz jeżeli zachodzi uzasadnione przypuszczenie, że niestawiennictwo wynikło z powodu przeszkód żywiołowych lub innych wyjątkowych przyczyn, a także wtedy, gdy osoba ta usprawiedliwiła należycie niestawiennictwo i wnosi o nieprzeprowadzanie czynności bez jej obecności, chyba że ustawa stanowi inaczej. Obowiązek wykazania niemożności wzięcia udziału w czynności procesowej obciąża osobę, która na taki fakt się powołuje. Reguła określona w tym przepisie ma charakter gwarancyjny dla uczestników postępowania, nie różnicuje ich sytuacji $\mathrm{z}$ uwagi na status $\mathrm{w}$ procesie, traktując ich $\mathrm{w}$ ten sam sposób ${ }^{8}$. Organ procesowy przed podejmowaniem czynności procesowych bada z urzędu, czy zachodzą okoliczności usprawiedliwiające niestawiennictwo uprawnionego do wzięcia w niej udziału9. Zasadniczo w świetle art. 117 § 2 in fine k.p.k. czynności procesowej nie przeprowadza się, gdy osoba usprawiedliwiła należycie niestawiennictwo i wnosi o nieprzeprowadzanie czynności bez jej obecności, chyba że ustawa stanowi inaczej (art. 117 § 2 k.p.k.). Lege non distinguente art. 378a k.p.k. stanowi lex specialis w stosunku do treści art. $117 \S 2$ k.p.k. ${ }^{10}$.

Przed wejściem w życie noweli prowadzenie rozprawy pod nieobecność oskarżonego, który usprawiedliwił swoją nieobecność i wnosił o nieprze-

${ }^{6}$ Wyr. SN z dnia 25 kwietnia 2013 r., III KK 360/12. LEX nr 1339082.

7 Wyr. SN z dnia 30 maja 2017 r., III KK 12/17. LEX nr 2320357.

8 Wyr. SN z dnia 6 listopada 2018 r., IV KK 421/17. LEX nr 2577395.

9 Wyr. SN z dnia 5 kwietnia 2016 r., SDI 8/16. LEX nr 2019580.

10 D. Świecki. W: Meritum. Postępowanie karne. Red. D. Świecki. Warszawa 2019, s. 907. 
prowadzenie czynności procesowych bez jego udziału, skutkowało zaistnieniem rażącego naruszenia prawa procesowego ${ }^{11}$. Jeszcze w poprzednim stanie prawnym ustawa karnoprocesowa przewidywała możliwość prowadzenia rozprawy pod nieobecność oskarżonego. Wspólnym mianownikiem dla tych układów procesowych jest zawinione zachowanie oskarżonego (np. wprawienie się ze swej winy w stan powodujący niezdolność do udziału w rozprawie - art. 377 \$ 1 k.p.k. - bądź też brak zainteresowania przebiegiem postępowania - art. $376 \S 1$ zd. pierwsze k.p.k., art. $377 \S 1$ i 3 k.p.k.). Celem powyższych regulacji jest zapewnienie możliwości procedowania w wypadkach, w których oskarżony w sposób świadomy i celowy chciałby „torpedować” toczące się przeciwko niemu postępowanie karne. W przeciwieństwie do powyższych przepisów art. 378a k.p.k. daje sądowi legitymację do procedowania per absentia w sytuacji, gdy oskarżony z przyczyn od siebie niezależnych nie może wziąć udziału w rozprawie, choć wyraża taką wolę i jednocześnie usprawiedliwia swoją nieobecność w sposób przewidziany przez prawo karne procesowe.

Spełnienie powyższych warunków nie daje jeszcze możliwości procedowania pod nieobecność oskarżonego lub jego obrońcy. Warunkiem sine qua non sięgnięcia po art. 378a k.p.k. przez sąd meriti jest to, aby zachodziły szczególnie uzasadnione wypadki przemawiające za przeprowadzeniem postępowania dowodowego, nawet jeżeli oskarżony nie złożył jeszcze wyjaśnień. Przesłanka ta jest sui generis bezpiecznikiem, który chroni przed nadużywaniem tej instytucji karnoprocesowej. Przepis ma charakter ultima ratio, a organ procesowy powinien stosować go jedynie $\mathrm{w}$ wyjątkowych sytuacjach.

Pojęcie „szczególnie uzasadnione wypadki” jest pojęciem znanym ustawie karnoprocesowej (np. art. 73 § 1 i 2 k.p.k., 214 \$ 1 k.p.k., 310 $\S 2$ k.p.k. $325 \S 1$ k.p.k., $607 \mathrm{~m} \S 2$ k.p.k.). Ustawa nie precyzuje, czym są tego rodzaju sytuacje. Należy przyjąć, że chodzi o okoliczności ekstraordynaryjne, gdy zwłoka w przeprowadzeniu dowodu mogłaby prowadzić do jego utraty, zniekształcenia lub zniszczenia. Do tego katalogu zaliczyć można przykładowo konieczność przesłuchania świadka w stanie terminalnym czy też osoby, która zamierza opuścić kraj bezpowrotnie ${ }^{12}$. Chodzi o okoliczności relewantne z punktu widzenia możliwości dochodzenia do prawdziwych ustaleń faktycznych. Wprowadzenie tej przesłanki stanowi swoisty hamulec przed nadużywaniem instytucji i w sposób znaczący łagodzi jej represyjny charakter. Natomiast nie powinna być podstawą do sięgania po art. 378a k.p.k. sytuacja, w której istnieje fak-

11 Wyr. SN z dnia 6 listopada 2018 r., IV KK 421/17. LEX nr 2577395.

12 Por. J. Zagrodnik. W: Kodeks postępowania karnego. Komentarz. Red. J. SkorUPKA. Legalis, art. 378a, nb. I.4. 
tyczna możliwość przeprowadzenia danego dowodu $\mathrm{w}$ innym terminie (np. uzupełniające przesłuchanie biegłych psychiatrów). O ile ponowne wzywanie świadków bądź biegłych może być dla nich kłopotliwe i wiązać się z dodatkowymi obciążeniami, w tym finansowymi, to nie może zejść z pola widzenia, że postępowanie karne dotyczy przede wszystkim osoby, co do której wniesiono oskarżenie do sądu. Proces karny jest procesem oskarżonego i to ochrona jego gwarancji procesowych powinna mieć decydujące znaczenie przy podejmowaniu decyzji o prowadzeniu rozprawy per absentia. Brak złożenia wyjaśnień przez oskarżonego nie stanowi przeszkody w przeprowadzeniu postępowania per absentia, co na tej płaszczyźnie przypomina rozwiązania normatywne określone w art. art. 377 $\S 1$ i 4 k.p.k.

Przepis art. 378a $\S 1$ k.p.k. ma charakter fakultatywny, co oznacza, że przeprowadzenie postępowania dowodowego przez sąd należy do jego władzy uznaniowej (dyskrecjonalnej). Jest w pełni uzasadnione, aby to sąd ad casum podejmował w realiach konkretnej sprawy decyzję procesową o przeprowadzeniu postępowania dowodowego per absentia. Fakultatywność instytucji zapewnia minimalną ochronę gwarancji procesowych oskarżonego. Ustawa karnoprocesowa nakłada na organy procesowe liczne obowiązki notyfikacyjne związane z omawianą instytucją. Oskarżony musi zostać poinformowany o treści art. 378a k.p.k. wraz z przesłaniem aktu oskarżenia (art. 334 § 3 zd. pierwsze k.p.k.) oraz przy zawiadomieniu albo wezwaniu na rozprawę (art. $353 \S 4$ k.p.k.). Ponadto stosownie do art. 378a $\S 7$ k.p.k. w przypadku skorzystania przez sąd z możliwości prowadzenia postępowania dowodowego per absentia w kolejnym terminie rozprawy $\mathrm{w}$ przypadku obecności uprawnionego przewodniczący ma obowiązek pouczenia go o możliwości złożenia wniosku o uzupełniające przeprowadzenie dowodu, w szczególności o terminie maksymalnym jego złożenia oraz o skutkach procesowych uchybienia temu terminowi.

\section{Ratio legis regulacji}

W uzasadnieniu Rządowego projektu ustawy o zmianie ustawy Kodeks postępowania karnego oraz niektórych innych ustaw (Druk Sejmowy nr 3251) podkreślano, że wprowadzenie art. 378a k.p.k. ma na celu zadośćuczynienie zasadzie szybkości procesu. Projektodawca akcentował, że konieczność odraczania oraz przerywania rozpraw w przypadku usprawiedliwionej obecności oskarżonych i obrońców paraliżuje procesy, pociąga za sobą duże koszty społeczne (ponowne wzywanie świadków, biegłych), jak i wiąże się z dużymi nakładami finansowymi (poniesieniem 
większych środków pieniężnych na zorganizowanie kolejnych terminów rozprawy głównej) $)^{13}$.

Ponadto wskazywano, że podobna regulacja występuje też na gruncie postępowania w sprawach o wykroczenia, co przemawia za wprowadzeniem art. 378a k.p.k. do polskiego procesu karnego. Zgodnie z art. 71 $\S 2$ k.p.w. jeżeli oskarżyciel publiczny, oskarżyciel posiłkowy, pokrzywdzony lub obwiniony nie stawił się na rozprawę i w aktach sprawy brak jest dowodu doręczenia mu wezwania lub zawiadomienia, rozprawę odracza się, przy czym sąd może, jeżeli uzna to za celowe, przeprowadzić postępowanie dowodowe, a w szczególności przesłuchać świadków, którzy stawili się na rozprawę. Na następnej rozprawie dowody te przeprowadza się ponownie tylko wówczas, jeżeli zażąda tego strona nieobecna na poprzedniej rozprawie, chyba że była o jej terminie prawidłowo powiadomiona. Przepis ten ma odpowiednie zastosowanie $\mathrm{w}$ razie niestawiennictwa prawidłowo powiadomionego obrońcy, gdy jego stawiennictwo jest obowiązkowe (art. 71 § 3 k.p.w.).

Zwiększenie szybkości procesu karnego jest celem społecznie oczekiwanym i pożądanym, niewątpliwie wpływa na pozytywny odbiór całego wymiaru sprawiedliwości. Nie może być jednak asumptem do procedowania w sposób mniej wnikliwy, rzetelny, ze szkodą dla zasady prawdy materialnej. W orzecznictwie trafnie podnosi się, że z dążenia do dochodzenia prawdziwych ustaleń faktycznych nie można rezygnować wyłącznie dla spełnienia postulatu szybkiego rozpoznania sprawy karnej ${ }^{14}$.

Odnosząc się do drugiego argumentu podnoszonego w uzasadnieniu projektu, należy zauważyć, że nie uwzględnia on odmiennej specyfiki postępowania $\mathrm{w}$ sprawach o wykroczenia. W sprawach o wykroczenia społeczna szkodliwość czynu jest zdecydowanie mniejsza niż przy przestępstwach. Postępowanie to, choć ma charakter represyjny, nie jest postępowaniem karnym. Poza tym normy określone w art. 71 § 2 i 3 k.p.w. nie odnoszą się do sytuacji należytego usprawiedliwienia nieobecności przez obwinionego, gdy wnosił on o nieprzeprowadzenie czynności bez jego udziału.

Na gruncie postępowania karnego jedną z kluczowych reguł jest zasada bezpośredniości. Ustawa karnoprocesowa kładzie nacisk na to, żeby sąd zapoznał się w sposób „namacalny” z każdym przeprowadzonym dowodem. Wyjątki od powyższej zasady mają charakter ekstraordynaryjny, inaczej niż ma to miejsce na gruncie postępowania w sprawach o wykroczenia. Przykładowo w świetle art. 67 § 3 k.p.w. w przypadku, gdy

13 Rządowy projekt ustawy o zmianie ustawy - Kodeks postępowania karnego oraz niektórych innych ustaw (Druk Sejmowy nr 3251), s. 42-43.

${ }^{14}$ Wyr. SA w Łodzi z dnia 22 stycznia 2001 r., II AKa 249/00. LEX nr 55375. 
nie uznano udziału obwinionego w rozprawie za obowiązkowy, może on w ogóle nie stawiać się do sądu i nadesłać swoje wyjaśnienia tylko w formie pisemnej. W takim układzie wyjaśnienia te podlegają odczytaniu na rozprawie, która ma wówczas charakter zaoczny. Analogiczne rozwiązanie przyjęto na gruncie tzw. czynności wyjaśniających, gdzie istnieje możliwość odstąpienia od przesłuchania osoby podejrzanej o popełnienie wykroczenia, jeżeli byłoby ono połączone ze znacznymi trudnościami. Osoba ta może nadesłać wyjaśnienia do właściwego organu w terminie 7 dni od odstąpienia od przesłuchania, o czym należy ją pouczyć (art. 54 $\S 7$ k.p.w.). Wyjaśnienia utrwalone w formie pisemnej stanowią pełnoprawny dowód i mogą być podstawą wyrokowania. Tymczasem oskarżony $\mathrm{w}$ procesie karnym zasadniczo nie ma możliwości artykułowania przed sądem wyjaśnień $\mathrm{w}$ formie pisemnej. Specyficzny charakter postępowania w sprawach o wykroczenia pozwala na dalej idące wyjątki od zasady bezpośredniości. Nie jest ono bowiem prowadzone w przedmiocie odpowiedzialności karnej.

\section{Standard prawa do realnej obrony a przepis art. 378a k.p.k.}

Sąd rozstrzygający w przedmiocie odpowiedzialności karnej powinien dążyć do wydania sprawiedliwego orzeczenia poprzez zastosowanie szeregu instrumentów procesowych, które bilansują interesy procesowe podsądnego oraz wymiaru sprawiedliwości. Jednym $\mathrm{z}$ nich jest niewątpliwie prawo do obrony, które zgodnie z wysokimi standardami rzetelnego procesu karnego musi mieć charakter rzeczywisty, a nie jedynie pozorny ${ }^{15}$. Po stronie ustawodawcy ciąży obowiązek tworzenia mechanizmów pozwalających podsądnemu na odpieranie zarzutów oskarżenia. Ponadto ich specyfika musi być dostosowana do aktualnego etapu postępowania ${ }^{16}$.

Jednym z podstawowych elementów prawa do obrony, a w szerszym ujęciu także prawa do sądu jest możliwość przedstawienia swojego stanowiska $\mathrm{w}$ procesie karnym ${ }^{17}$. Prawo do bycia wysłuchanym (right to be heard) konkretyzuje się zwłaszcza poprzez umożliwienie oskarżone-

15 Wyr. SN z dnia 7 lipca 2006 r., III KK 418/05. LEX nr 193010; wyr. ETPC z dnia 25 lipca 2017 r. (skarga nr 2156/10). LEX nr 2326512.

16 Wyr. TK z dnia 28 listopada 2007 r., K 39/07. LEX nr 319447; wyr. SA w Lublinie z dnia 5 marca 1999 r., II AKa 123/98. LEX nr 36277.

17 Wyr. SN z dnia 11 czerwca 2014 r., III KK 38/14. LEX nr 1477445; wyr. SN z dnia 8 stycznia 2014 r., IV KK 264/13. LEX nr 1428993; wyr. SN z dnia 10 kwietnia 2014 r., III KK 385/13. LEX nr 1463893. 
mu wzięcia udziału w rozprawie ${ }^{18}$. Na konieczność zapewnienia oskarżonemu prawa do udziału $\mathrm{w}$ rozprawie wskazuje expressis verbis art. 14 ust. 3 lit. d MPPOiP oraz art. 8 ust. 1 Dyrektywy Parlamentu Europejskiego i Rady (UE) 2016/343 z dnia 9 marca 2016 r. w sprawie wzmocnienia niektórych aspektów domniemania niewinności i prawa do obecności na rozprawie w postępowaniu karnym (Dz.U.UE L 2016, nr 65, poz. 1) [dalej jako: Dyrektywa]. Stosownie do treści art. 14 ust. 3 lit. d MPPOiP każda osoba oskarżona o popełnienie przestępstwa ma prawo, na zasadach pełnej równości, co najmniej do obecności na rozprawie oraz bronienia się osobiście ${ }^{19}$. Natomiast art. 8 ust. 1 Dyrektywy zakłada, że państwa członkowskie zapewniają podejrzanym lub oskarżonym prawo do obecności na rozprawie. Dyrektywa przewiduje dwa układy procesowe, w których istnieje możliwość procedowania pod nieobecność oskarżonego. Taka aktywność jest dopuszczalna, po pierwsze, jeżeli oskarżonego powiadomiono we właściwym czasie o rozprawie i o konsekwencjach niestawiennictwa (art. 8 ust. 2 lit. a Dyrektywy). Po drugie, prowadzenie rozprawy per absentia jest możliwe, jeżeli jest on reprezentowany przez obrońcę z wyboru albo z urzędu (art. 8 ust. 2 lit. b Dyrektywy). Uprawnienie do osobistego udziału w rozprawie można wywodzić także z art. 42 Konstytucji RP, art. 6 ust. 3 lit. c EKPC oraz art. 6 k.p.k. Zgodnie z art. 42 ust. 2 zd. pierwsze Konstytucji RP każdy, przeciw komu prowadzone jest postępowanie karne, ma prawo do obrony we wszystkich stadiach postępowania. W świetle art. 6 ust. 3 lit. c EKPC każdy oskarżony o popełnienie czynu zagrożonego karą ma co najmniej prawo do bronienia się osobiście. Powyższe normy akcentują prawo oskarżonego do podejmowania samodzielnych akcji obrończych. W takim rozumieniu udział oskarżonego w rozprawie stanowi podstawową płaszczyznę do realizacji obrony materialnej ${ }^{20}$.

18 Wyr. ETPC z dnia 26 lipca 2018 r. (skarga nr 35778/11). LEX nr 2553418; wyr. SN z dnia 26 czerwca 2002 r., III KK 205/02. LEX nr 53898; wyr. SN z dnia 26 czerwca 2002 r., III KK 205/02. LEX nr 53898; wyr. SN z dnia 24 października 2003 r., III DS 5/02. LEX nr 113812; wyr. ETPC z dnia 26 lipca 2018 r. (skarga nr 35778/11). LEX nr 2553418; wyr. ETPC z dnia 4 kwietnia 2018 r. (skarga nr 56402/12). LEX nr 2467668; wyr. SN z dnia 16 lutego 2011 r., III KK 275/10. LEX nr 784956; S. STACHOWIAK: Rozprawa główna prowadzona pod nieobecność oskarżonego $w$ polskim procesie karnym. PiP 1999, nr 4, s. 7; T. KoncewICZ: Prawo do rzetelnego postępowania $w$ europejskiej przestrzeni prawnej. Jaka procedura? Jakie prawo?. Pal. 2013, nr 11-12, s. 67.

19 Międzynarodowy Pakt Praw Obywatelskich i Politycznych otwarty do podpisu w Nowym Jorku dnia 19 grudnia 1966 r., Dz.U. 1977, nr 38, poz. 167.

${ }^{20}$ Wyr. SN z dnia 4 lutego 2003 r., IV KK 379/02. LEX nr 75448; wyr. SN z dnia 1 września 2016 r., IV KK 78/16. LEX nr 2108509; wyr. SN z dnia 10 marca 2010 r., V KK 401/09. LEX nr 844056. 
W zależności od przyjętej linii obrony oskarżony może podjąć obronę aktywną albo zachowywać się pasywnie ${ }^{21}$.

Europejski Trybunał Praw Człowieka w swoim bogatym orzecznictwie podkreśla, że przeprowadzenie przesłuchania świadków powinno mieć miejsce co do zasady w drodze jawnej i kontradyktoryjnej rozprawy ${ }^{22}$. Prawo to powinno być skutecznie zagwarantowane na rozprawie głównej przed sądem meriti, gdzie przeprowadza się zasadniczo wszystkie zgromadzone $\mathrm{w}$ sprawie dowody ${ }^{23}$. W takim ujęciu zapewnienie oskarżonemu prawa do udziału $\mathrm{w}$ rozprawie jako podstawowym forum rozpoznania sprawy karnej leży w interesie rzetelnego procesu karnego ${ }^{24}$. Możliwość prowadzenia sporu $\mathrm{w}$ przedmiocie odpowiedzialności karnej nie tylko zapewnia możność powzięcia wiedzy o treści wypływającej z dowodów zaprezentowanych przez stronę przeciwną, ale również ustosunkowanie się do nich $\mathrm{w}$ sposób przewidziany przez prawo karne procesowe ${ }^{25}$. Przesłuchanie świadków obrony i oskarżenia na takich samych warunkach ma na celu zapewnienie pełnej równości broni (equal arms $)^{26}$. W wyroku Europejskiego Trybunału Praw Człowieka z dnia 19 lutego 2013 r. w sprawie Gani przeciwko Hiszpanii trafnie zauważono, że wydanie rozstrzygnięcia w oparciu o zeznania świadka w sytuacji, w której ani oskarżony, ani jego obrońca nie mieli faktycznej możliwości jego przesłuchania, godzi w sposób oczywisty w standard rzetelnego procesu karnego ${ }^{27}$.

Reglamentacja tego uprawnienia może występować tylko w ekstraordynaryjnych wypadkach i być uzasadniona szczególnymi okolicznościami konkretnej sprawy karnej. Kontestowanie depozycji osób przesłuchiwanych, zadawanie pytań powinno mieć miejsce bezpośrednio podczas rozprawy, na której świadek składa zeznania, a tylko w szczególnie uzasadnionych wypadkach na późniejszym etapie ${ }^{28}$. W takim ujęciu przepis

${ }^{21}$ D. Drajewicz: Czasowe usunięcie oskarżonego z sali rozpraw w postępowaniu karnym. PS 2014, nr 7-8, s. 126.

22 Wyr. ETPC z dnia 6 grudnia 1988 r. (skarga nr 10590/83). LEX nr 81047; wyr. ETPC z dnia 7 czerwca 2018 r. (skarga 35132/08). LEX nr 2497923; wyr. ETPC z dnia 29 marca 2016 r. (skarga nr 7459/04). LEX nr 2008630.

${ }^{23}$ Wyr. ETPC z dnia 21 lipca 2009 r. (skarga nr 3818/04). LEX nr 511085; wyr. ETPC z dnia 25 marca 1998 r. (skarga nr 23103/93). LEX nr 40781; wyr. ETPC z dnia 9 czerwca 2009 r. (skarga nr 19847/07). LEX nr 504311; wyr. ETPC z dnia 9 czerwca 2009 r. (skarga nr 31509/02). LEX nr 504337.

${ }^{24}$ Wyr. ETPC z dnia 27 sierpnia 2019 r. (skarga nr 32631/09). LEX nr 2713495.

25 Wyr. ETPC z dnia 23 czerwca 1993 r. (skarga nr 12952/87). LEX nr 80578.

${ }^{26}$ Wyr. ETPC z dnia 7 czerwca 2018 r. (skarga nr 17716/08). LEX nr 2497960.

27 Wyr. ETPC z dnia 19 lutego 2013 r. (skarga nr 61800/08). LEX nr 1271549.

28 Wyr. ETPC z dnia 17 kwietnia 2012 r. (skarga nr 43609/07). LEX nr 1147991; wyr. ETPC z dnia 23 stycznia 2018 r. (skarga nr 58683/08). LEX nr 2428733; wyr. ETPC z dnia 17 września 2013 r. (skarga nr 23789/09). LEX nr 1363098; wyr. ETPC 
art. 378a k.p.k. pozostaje w oczywistej kolizji z wypracowanymi przez Europejski Trybunał Praw Człowieka standardami. Należy dostrzec, że zgodnie z treścią art. $390 \S 1$ k.p.k. oskarżony ma prawo być obecny przy wszystkich czynnościach postępowania dowodowego. Na rozprawie - zgodnie z zasadą bezpośredniości - sąd przeprowadza postępowanie dowodowe, które następnie staje się podstawą do wydania wiążącego rozstrzygnięcia. Oskarżony ma w szczególności prawo do: złożenia wyjaśnień, odpowiadania na pytania wszystkich lub tylko wybranych uczestników postępowania (art. $176 \S 1$ k.p.k.), wypowiadania się co do każdej kwestii podlegającej rozstrzygnięciu (art. 367 § 1 k.p.k.), zabierania głosu, gdy w jakiejkolwiek kwestii inna strona skorzystała $\mathrm{z}$ tego uprawnienia (art. 367 § 2 k.p.k.), zadawania pytań osobom przesłuchiwanym (art. 370 § 2 k.p.k.), składania wniosków dowodowych (art. 167 k.p.k.), zaprezentowania głosu końcowego (art. $406 \S 1$ k.p.k.) oraz skorzystania z tzw. prawa do repliki (art. 406 § 2 k.p.k.). Tymczasem na gruncie art. 378a k.p.k. ustawa nie ogranicza organu procesowego pod względem ilości przeprowadzonych dowodów oraz ich rodzaju ${ }^{29}$. Sąd może zasadniczo przeprowadzić każdy dowód mający znaczenie z punktu widzenia przedmiotu postępowania. Przepis jedynie przykładowo wskazuje na dowód z przesłuchania świadka, o czym świadczy określenie „w szczególności”. Wobec tego istnieje możliwość przeprowadzenia przewodu sądowego nawet w znacznej części pod nieobecność oskarżonego lub jego obrońcy. Należy przyjąć, że sąd, który sięgnął po instytucje określoną w art. 378a k.p.k., nie może jednak zamknąć przewodu sądowego, nawet gdy w jego ocenie zebrany $\mathrm{w}$ sprawie materiał dowodowy jest już kompletny ${ }^{30}$. Przyjęcie odmiennej wykładni prowadziłoby do oczywistego pogwałcenia prawa oskarżonego do obrony, skoro ustawodawca daje możliwość złożenia wniosku o uzupełniające przeprowadzenie dowodu najpóźniej na kolejnym terminie rozprawy.

W tak zakreślonym układzie procesowym oskarżony traci prawo do podejmowania skutecznych akcji obrończych. Strona bierna nie ma wpływu na wygłaszane przez osobowe źródło dowodowe oświadczenia procesowe z uwagi na brak możliwości zadawania pytań. Ponadto pozbawiona jest możliwości obserwowania sposobu ich artykulacji (mowy ciała świadka/biegłego/współoskarżonego), co nie pozwala na dogłębną ocenę składanych przez niego relacji. Oskarżony może zapoznać się ze składanymi oświadczeniami jedynie post factum $\mathrm{w}$ drodze lektury protokołu roz-

z dnia 27 kwietnia 2010 r. (skarga nr 43643/04). LEX nr 576523; wyr. ETPC z dnia 4 maja 2017 r. (skarga nr 15485/09). LEX nr 2278004.

29 P. MiszTal. W: Meritum..., s. 320.

30 Wyr. SO w Gliwicach z dnia 29 listopada 2019 r., VI Ka 946/19. LEX nr 2777546. 
prawy. W takim wypadku informacje wypływające $\mathrm{z}$ dowodu otrzymuje niejako w gotowej formie. Zasadnie podnosi K. Gajowniczek- Pruszyńska, że w praktyce stosowania prawa pytania zadawane świadkowi często nie są protokołowane, co proces ten znacząco utrudnia ${ }^{31}$. Nieobecność uprawnionego uniemożliwia mu faktyczne zgłoszenie wniosku o sprostowanie protokołu rozprawy $\mathrm{z}$ uwagi na nieścisłości i opuszczenia $\mathrm{w}$ trybie art. 152 k.p.k., o ile przebieg czynności procesowych nie jest rejestrowany (zob. art. 147 k.p.k.).

\section{Wniosek o uzupełniające przeprowadzenie dowodu}

Zgodnie z treścią art. 378a $§ 3$ k.p.k. oskarżony lub jego obrońca może złożyć wniosek o uzupełniające przeprowadzenie dowodu. Warto zaakcentować, że w uzasadnieniu projektu rządowego dwukrotnie użyto stwierdzenia „ponowne przeprowadzenie dowodu”, co w istocie pozostaje $\mathrm{w}$ sprzeczności z treścią ostatecznie uchwalonego przepisu ${ }^{32}$. Należy przyjąć, że nie jest możliwe przeprowadzenie tego samego dowodu w pełnym zakresie (ab initio). Nie jest zatem dopuszczalne ponowne przeprowadzenie danego dowodu w całości. Uprawniony może postulować przesłuchanie świadka celem poszerzenia lub zweryfikowania pewnych okoliczności, które zostały już wyartykułowane przez osobowe źródło dowodowe, jak i po to, aby poprzez nowe pytania uzyskać wiedzę procesową co do innych faktów relewantnych z punktu widzenia przedmiotu procesu.

Wniosek może zostać złożony ustnie do protokołu rozprawy, a także $\mathrm{w}$ formie pisemnej. Przepis art. 378a k.p.k. nie zawiera bowiem szczególnych wymogów co do jego formy. W istocie tego rodzaju pismo procesowe jest sui generis wnioskiem dowodowym, a więc powinno odpowiadać zarówno ogólnym (art. 119 § 1 k.p.k.), jak i szczególnym wymogom formalnym (art. 169 § 1 k.p.k., art. 378a § 5 k.p.k.). Na oskarżonym cią-

${ }^{31}$ K. Gajowniczek-PruszyńsKa. W: Kodeks postępowania karnego. Komentarz do ustawy $z$ 19.7.2019 r. Red. P. Karlik, K. GajowniczeK-PruszyńsKa. Legalis, art. 378a, nb. V.1.

${ }^{32} \mathrm{~W}$ uzasadnieniu projektu rządowego wskazano, że „zabezpieczenie gwarancji procesowych oskarżonego ma zapewnić regulacja, wedle której w razie złożenia umotywowanego wniosku przez uczestnika, który z usprawiedliwionych przyczyn nie stawił się na rozprawę, dowód ten będzie należało przeprowadzić ponownie w zakresie, w którym nastąpiło naruszenie tych gwarancji poprzez przesłuchanie tej osoby w nieobecności uprawnionego [...], jednocześnie jest konieczne wprowadzenie terminu do złożenia wniosku o ponowne przeprowadzenie dowodu, gdyż strony mogą się zapoznać z przebiegiem dotychczasowego postępowania dowodowego przeprowadzonego podczas ich nieobecności i wyłącznie na tej podstawie podjąć decyzję odnośnie do ponowienia żądania przeprowadzenia dowodu [...]". 
ży także powinność sformułowania tezy dowodowej. Zgodnie z art. 378 § 5 k.p.k. we wniosku o uzupełniające przeprowadzenie dowodu oskarżony lub obrońca ma obowiązek wykazać, że sposób przeprowadzenia dowodu podczas jego nieobecności naruszał gwarancje procesowe, w szczególności prawo do obrony. Uprawniony do złożenia wniosku musi udowodnić, że sposób przeprowadzenia dowodu był wadliwy. Innymi słowy chodzi o sytuację, w której określone fakty uzyskano w sposób niezgodny z wymogami Kodeksu postępowania karnego. Przykładowo uprawniony może wykazać, że przesłuchiwany świadek nie został pouczony o odpowiedzialności karnej za zeznanie nieprawdy lub zatajenie prawdy (art. 190 § 1 k.p.k.); organ procesowy uniemożliwił osobie przesłuchiwanej swobodne wypowiedzenie się co do treści danej czynności (art. $171 \S 1$ k.p.k.) albo zastosowano niedozwolone metody przesłuchania (np. poprzez wpływanie na wypowiedzi osoby przesłuchiwanej za pomocą przymusu lub groźby bezprawnej, stosowanie hipnozy albo środków chemicznych lub technicznych wpływających na procesy psychiczne osoby przesłuchiwanej albo mających na celu kontrolę nieświadomych reakcji jej organizmu w związku z przesłuchaniem). W świetle powyższych rozważań należy podkreślić, że już samo przeprowadzenie postępowania dowodowego per absentia w trybie art. 378a k.p.k. automatycznie godzi $\mathrm{w}$ interesy procesowe oskarżonego ${ }^{33}$. Wadliwość ta pojawia się ipso facto z chwilą podjęcia czynności przez sąd. Oskarżony, który nie uczestniczy $\mathrm{w}$ rozprawie $\mathrm{z}$ przyczyn niezawinionych, zostaje pozbawiony prawa do aktywnego udziału w czynności procesowej, w szczególności nie może uczestniczyć w zadawaniu pytań osobie przesłuchiwanej oraz wypowiadać się co do treści przeprowadzonego dowodu. Taka aktywność organu procesowego w sposób oczywisty może prowadzić do zniekształcenia poczynionych na tej podstawie ustaleń faktycznych.

Literalna wykładnia art. 378a § 6 k.p.k. wskazuje na to, że wniosek oskarżonego lub jego obrońcy nie ma dla organu procesowego wiążącego charakteru, o czym świadczy zwrot „w razie uwzględnienia wniosku”, a organ procesowy podejmuje decyzję o charakterze autonomicznym. W przypadku, gdyby wniosek oskarżonego lub jego obrońcy o uzupełniające przeprowadzenie dowodu nie został uwzględniony, to na etapie skargi apelacyjnej skarżący powinien podnieść zarzut naruszenia prawa procesowego, które miało istotny wpływ na treść rozstrzygnięcia (art. 378a § 3,5 i 6 k.p.k. w zw. z art. 6 k.p.k.) poprzez pozbawienie go prawa do rzeczywistej obrony. W ujęciu art. 378a $\$ 4$ k.p.k. w apelacji można podnosić zarzuty, które nie mogły stanowić przedmiotu zażalenia.

${ }^{33}$ P. Misztal. W: Meritum..., s. 321; J. Zagrodnik: Komentarz do art. 378 a k.p.k. Kodeks postępowania karnego. Komentarz praktyczny do nowelizacji 2019. LEX/el. 2020. 
De lege ferenda należy opowiedzieć się za stanowiskiem, że samo złożenie oświadczenia przez oskarżonego lub jego obrońcę powinno obligować organ do uzupełniającego przeprowadzenia dowodu w zakresie, $\mathrm{w}$ jakim jest to konieczne dla zadośćuczynienia gwarancji procesowych oskarżonego. Powyższa konstatacja koreluje $\mathrm{z}$ argumentem podniesionym na łamach niniejszego opracowania, że przeprowadzenie dowodu na warunkach określonych $\mathrm{w}$ art. 378a k.p.k. niejako automatycznie narusza gwarancje procesowe strony biernej. Dowodem jest bowiem wszystko to, co ma znaczenie dla rozstrzygnięcia i jest dopuszczalne przez prawo karne procesowe $^{34}$. Stosownie do art. $170 \S 1$ pkt 2, 3 k.p.k. jeżeli dana okoliczność jest nieprzydatna lub nie ma znaczenia dla rozstrzygnięcia, nie może w ogóle stanowić dowodu.

$\mathrm{W}$ świetle art. 378a $§ 4$ k.p.k. w razie niezłożenia wniosku w terminie prawo do jego złożenia wygasa i w dalszym postępowaniu nie jest dopuszczalne podnoszenie zarzutu naruszenia gwarancji procesowych, w szczególności prawa do obrony, wskutek przeprowadzenia tego dowodu podczas nieobecności oskarżonego lub obrońcy. Przepis przewiduje dwa skutki procesowe. Po pierwsze przekroczenie terminu oznacza bezskuteczność czynności procesowej. Kodeks postępowania karnego nie posługuje się w żadnym przepisie określeniem „wygasa”. Należy przyjąć, że intencją ustawodawcy było wprowadzenie swoistej prekluzji. Wobec tego termin ten ma charakter nieprzekraczalny i nieprzywracalny. Lege non distinguente po jego upływie oskarżony traci możliwość powoływania się na uchybienie gwarancjom procesowym $\mathrm{w}$ dalszym toku postępowania. Wniesienie apelacji w oparciu o tego rodzaju zarzut literalnie skutkować musi odmową przyjęcia środka odwoławczego (art. 429 § 1 k.p.k.) albo pozostawieniem go bez rozpoznania (art. 430 § 1 k.p.k.) z uwagi na jego niedopuszczalność. Po drugie podobne pod względem skutków prawnych rozwiązanie przewiduje regulacja wskazana w art. $447 \S 5$ k.p.k. ${ }^{35}$. Omawiany przepis niejako legalizuje naruszenia sądu meriti, co pozostaje w oczywistej sprzeczności ze standardami rzetelnego procesu karnego. Nieuzasadnione sięgnięcie po art. 378a k.p.k. może prowadzić do rażącej niesprawiedliwości wydanego przez sąd a quo orzeczenia, co w przypadku wniesienia apelacji powinno być przedmiotem kontroli przez sąd ad quem także z urzędu, w oparciu o treść art. 433 § 2 k.p.k.

Prawo do złożenia wniosku nie przysługuje, jeżeli okaże się, że nieobecność oskarżonego lub obrońcy na terminie rozprawy, na którym przeprowadzono postępowanie dowodowe, była nieusprawiedliwiona (art. 378a $\S 3$ zd. drugie k.p.k.). Powyższe rozwiązanie należy ocenić pozytywnie.

34 T. Grzegorczyk, J. Tylman: Polskie postępowanie karne. Warszawa 2009, s. 427.

35 P. Misztal. W: Meritum..., s. 322. 
Skoro bowiem oskarżony zrezygnował w sposób dobrowolny i świadomy z uczestnictwa w części rozprawy, to nie może powołać się na naruszenie jego prawa do obrony. $\mathrm{W}$ przeciwnym razie dochodziłoby do swoistego nadużywania prawa podmiotowego i paraliżowania postępowania.

\section{Podsumowanie}

Możliwość prowadzenia rozprawy na zasadach określonych w art. 378a k.p.k. w sposób znaczący godzi w gwarancje procesowe nie tylko oskarżonego, ale także całego wymiaru sprawiedliwości. Pozbawienie oskarżonego prawa do obrony osobistej wynikające z przeprowadzenia rozprawy per absentia, pomimo należytego usprawiedliwienia jego nieobecności, wyłącznie dla przyspieszenia postępowania narusza zasadę prawdy materialnej. Zasada prawdy jako „królowa zasad” ma niekwestionowane $\mathrm{w}$ doktrynie i orzecznictwie pierwszeństwo przed pozostałymi regułami kształtującymi model postępowania karnego. O ile przyspieszenie postępowania jest oczekiwane i pożądane, to instrumenty, które zmierzają do tego celu, nie mogą powodować naruszenia interesów oskarżonego i narażać prestiżu wymiaru sprawiedliwości. Postulując de lege ferenda, należałoby albo całkowicie wyrugować z polskiego porządku prawnego omawianą instytucję procesową albo też poszerzyć już istniejące i omówione na kanwie niniejszego opracowania „bezpieczniki”, tak aby prowadzenie postępowania dowodowego pod nieobecność oskarżonego lub jego obrońcy nie oznaczało automatycznego naruszenia standardów rzetelnego procesu karnego. Jednym $\mathrm{z}$ takich sposobów byłoby niewątpliwie obligatoryjne rejestrowanie obrazu i dźwięku z czynności dowodowych procedowanych per absentia. Podobne rozwiązanie przewiduje szczególny tryb przesłuchania małoletniego w trybie art. 185a k.p.k. Ustawa wyłącza ex lege możliwość wzięcia udziału w tej czynności procesowej. Przepis ten ma na celu zabezpieczenie gwarancji procesowych małoletniego pokrzywdzonego ${ }^{36}$. Norma ta przewiduje jednak mechanizmy, które zapewniają oskarżonemu prawo do podejmowania realnej obrony pomimo faktycznej nieobecności na posiedzeniu. Czynność przesłuchania jest rejestrowana, a następnie odtwarza się jej przebieg na rozprawie oraz odczytuje protokół, co pozwala na zajęcie stanowiska przez oskarżonego oraz odniesienie się do składanych przez pokrzywdzonego depozycji. Ponadto jeżeli oskarżony nie posiada obrońcy z wyboru, należy wyznaczyć mu obrońcę ad hoc.

Należałoby także rozważyć możliwość wniesienia sprzeciwu od postanowienia sądu przez prokuratora oraz pokrzywdzonego, tak jak ma to

36 Wyr. SA w Katowicach z dnia 14 grudnia 2018 r., II AKa 392/18. LEX nr 2728397. 
miejsce na gruncie konsensualnych sposobów zakończenia postępowania karnego. Nie może zejść z pola widzenia, że jednym z celów procesu jest ochrona prawnie chronionych interesów pokrzywdzonego przy poszanowaniu jego godności. Zbyt pochopne stosowanie art. 378a k.p.k. i tym samym konieczność uzupełniającego przeprowadzenia dowodu może prowadzić do powtórnej wiktymizacji pokrzywdzonego. Pokrzywdzony $\mathrm{w}$ tak zakreślonym układzie procesowym może być w toku postępowania jurysdykcyjnego przesłuchiwany aż dwukrotnie.

Jak się wydaje, to praktyka stosowania prawa wskaże, czy przepis ten stanie się furtką do nadużyć procesowych w świetle obowiązującego prawa, czy też będzie stosowany z rozwagą i tylko wtedy, kiedy jest to niezbędne i konieczne dla osiagnnięcia trafnej reakcji karnej, tak aby osoba winna poniosła odpowiedzialność, ale w ramach sprawiedliwego procesu.

\section{Bibliografia}

\section{Literatura}

DrajeWICZ D.: Czasowe usunięcie oskarżonego $z$ sali rozpraw $w$ postępowaniu karnym. PS 2014, nr 7-8.

GajownicZeK-PruszYŃsKa K. W: Kodeks postępowania karnego. Komentarz do ustawy $z$ 19.7.2019 r. Red. P. KarLIK, K. GaJownICZEK-PruszyŃsKa. Legalis, art. 378a, nb. V.1.

GrzegorczyK T., Tylman J.: Polskie postępowanie karne. Warszawa 2009.

Koncewicz T.: Prawo do rzetelnego postępowania $w$ europejskiej przestrzeni prawnej. Jaka procedura? Jakie prawo?. Pal. 2013, nr 11-12.

Misztal M. W: Meritum. Postępowanie karne. Red. D. ŚwieCKI. Warszawa 2019.

STACHOWIAK S.: Rozprawa główna prowadzona pod nieobecność oskarżonego $w$ polskim procesie karnym. PiP 1999, $\mathrm{nr} 4$.

ŚwIECKi D. W: Meritum. Postępowanie karne. Red. D. ŚwIECKI. Warszawa 2019.

ZAGRODNIK J.: Komentarz do art. 378 a k.p.k. Kodeks postępowania karnego. Komentarz praktyczny do nowelizacji 2019. LEX/el. 2020.

ZagrodniK J. W: Kodeks postępowania karnego. Komentarz. Red. J. SKorupKa. Legalis, art. 378a, nb. I.4.

ZAGRODNIK J.: Komentarz do art. 378 a k.p.k. Kodeks postępowania karnego. Komentarz praktyczny do nowelizacji 2019. LEX/el. 2020.

\section{Orzecznictwo}

Wyr. TK z dnia 6 grudnia 2004 r., SK 29/04. LEX nr 140349.

Wyr. TK z dnia 28 listopada 2007 r., K 39/07. LEX nr 319447.

Wyr. SN z dnia 26 czerwca 2002 r., III KK 205/02. LEX nr 53898.

Wyr. SN z dnia 4 lutego 2003 r., IV KK 379/02. LEX nr 75448.

Wyr. SN z dnia 24 października 2003 r., III DS 5/02. LEX nr 113812. 
Wyr. SN z dnia 7 lipca 2006 r., III KK 418/05. LEX nr 193010; Wyr. SN z dnia 10 marca 2010 r., V KK 401/09. LEX nr 844056. Wyr. SN z dnia 16 lutego 2011 r., III KK 275/10. LEX nr 784956. Wyr. SN z dnia 25 kwietnia 2013 r., III KK 360/12. LEX NR 1339082. Wyr. SN z dnia 8 stycznia 2014 r., IV KK 264/13. LEX nr 1428993. Wyr. SN z dnia 10 kwietnia 2014 r., III KK 385/13. LEX nr 1463893. Wyr. SN z dnia 11 czerwca 2014 r., III KK 38/14. LEX nr 1477445. Wyr. SN z dnia 5 kwietnia 2016 r., SDI 8/16. LEX nr 2019580. Wyr. SN z dnia 1 września 2016 r., IV KK 78/16. LEX nr 2108509. Wyr. SN z dnia 30 maja 2017 r., III KK 12/17. LEX nr 2320357. Wyr. SN z dnia 6 listopada 2018 r., IV KK 421/17. LEX nr 2577395. Wyr. SO w Gliwicach z dnia 29 listopada 2019 r., VI Ka 946/19. LEX nr 2777546. Wyr. SA w Lublinie z dnia 5 marca 1999 r., II AKa 123/98. LEX nr 36277. Wyr. SA w Łodzi z dnia 22 stycznia 2001 r., II AKa 249/00. LEX nr 55375. Wyr. SA w Katowicach z dnia 14 grudnia 2018 r., II AKa 392/18. LEX nr 2728397. Wyr. ETPC z dnia 25 marca 1998 r. (skarga nr 23103/93). LEX nr 40781. Wyr. ETPC z dnia 6 grudnia 1988 r. (skarga nr 10590/83). LEX nr 81047. Wyr. ETPC z dnia 9 czerwca 2009 r. (skarga nr 19847/07). LEX nr 504311 Wyr. ETPC z dnia 9 czerwca 2009 r. (skarga nr 31509/02). LEX nr 504337. Wyr. ETPC z dnia 21 lipca 2009 r. (skarga nr 3818/04). LEX nr 511085. Wyr. ETPC z dnia 27 kwietnia 2010 r. (skarga nr 43643/04). LEX nr 576523 Wyr. ETPC z dnia 17 kwietnia 2012 r. (skarga nr 43609/07). LEX nr 1147991. Wyr. ETPC z dnia 19 lutego 2013 r. (skarga nr 61800/08). LEX nr 1271549. Wyr. ETPC z dnia 17 września 2013 r. (skarga nr 23789/09). LEX nr 1363098. Wyr. ETPC z dnia 29 marca 2016 r. (skarga nr 7459/04). LEX nr 2008630. Wyr. ETPC z dnia 4 maja 2017 r. (skarga nr 15485/09). LEX nr 2278004. Wyr. ETPC z dnia 25 lipca 2017 r. (skarga nr 2156/10). LEX nr 2326512. Wyr. ETPC z dnia 23 stycznia 2018 r. (skarga nr 58683/08). LEX nr 2428733. Wyr. ETPC z dnia 4 kwietnia 2018 r. (skarga nr 56402/12). LEX nr 2467668. Wyr. ETPC z dnia 7 czerwca 2018 r. (skarga 35132/08). LEX nr 2497923. Wyr. ETPC z dnia 7 czerwca 2018 r. (skarga nr 17716/08). LEX nr 2497960. Wyr. ETPC z dnia 26 lipca 2018 r. (skarga nr 35778/11). LEX nr 2553418. Wyr. ETPC z dnia 27 sierpnia 2019 r. (skarga nr 32631/09). LEX nr 2713495.

\section{Źródła internetowe}

Opinia Rzecznika Praw Obywatelskich z dnia 20 grudnia 2018 r. do projektu ustawy ozmianie ustawy-Kodeks postępowania karnego orazniektórych innych ustaw. Źródło: https://www.rpo.gov.pl/sites/default/files/Wyst\%C4\%85pienie\%20do $\% 20$ Ministra $\% 20$ Sprawiedliwo \%C5\%9Bci\%20w\%20sprawie\%20projektu\%20noweli\%20Kodeksu\%20post\%C4\%99powania\%20karnego.pdf [dostęp: 15.03.2020].

Opinia Komisji Legislacyjnej przy Naczelnej Radzie Adwokackiej do projektu ustawy o zmianie ustawy - Kodeks postępowania karnego oraz niektórych innych ustaw (Druk UD 465), s. 33. Źródło: https://legislacja.rcl.gov. 
$\mathrm{pl} /$ docs//2/12318806/12554727/12554730/dokument377906.pdf [dostęp: 15.03.2020].

Opinia Ośrodka Badań, Studiów i Legislacji Krajowej Rady Radców Prawnych do projektu ustawy o zmianie ustawy - Kodeks postępowania karnego oraz niektórych innych ustawa z dnia 17 grudnia 2018 r. Zródło: http://obsil.pl/ wp-content/uploads/2018/12/Opinia-OBSiL-z-17.12.2018-r.-projekt-zmianKPK.pdf [dostęp: 15.03.2020]. 